\title{
Spatial distribution of climatic variables in Tocantins State, Brazil
}

\section{Distribuição espacial de variáveis climáticas no Estado do Tocantins}

\section{Léo Fernandes ÁVILA'; Felício CASSALHO²; Marcelo Ribeiro VIOLA; ; Samuel BESKOW ${ }^{4}$; Gilberto COELHO ${ }^{5}$; Kleudson da Silva NARDES ${ }^{6}$}

${ }^{1}$ Autor para correspondência, Engenheiro Agrícola, Universidade Federal de Goiás, Escola de Engenharia Civil e Ambiental,
avilalf@gmail.com
${ }^{2}$ Engenheiro Hídrico, Instituto Nacional de Pesquisas Espaciais, felicio.cassalho@inpe.br
${ }^{3}$ Engenheiro Agrícola, Universidade Federal de Lavras, marcelo.viola@ufla.br
${ }^{4}$ Engenheiro Agrícola, Universidade Federal de Pelotas, samuel.beskow@ufpel.edu.br
${ }^{5}$ Engenheiro Agrícola, Universidade Federal de Lavras, coelho@ufla.br
${ }^{6}$ Engenheiro Florestal, Universidade Federal de Tocantins, osnardes@hotmail.com

Recebido em: 11-06-2018; Aceito em: 07-04-2019

\begin{abstract}
The recognition of spatial distribution of climatic variables is essential for planning land use and occupation. This is especially relevant in regions where the agricultural frontier is expanding, as it is the case of Tocantins State, Brazil. One of the tools widely used for spatialization of environmental variables is geostatistics, which allows the identification of the spatial dependence of these variables. In this context, this study evaluates the performance of geostatistical interpolators ordinary kriging (OK) and cokriging (CK) by adjusting different semivariogram models, and the subsequent spatialization of the variables mean air temperature, insolation, air relative humidity, and potential evapotranspiration for Tocantins State. The main results and conclusions were: i) variogram analysis is essential to improve the mapping results of each variable; ii) cross-validation showed acceptable errors, indicating reliability of results; (iii) the OK outperformed CK, which can be explained by the good spatial dependence structure presented by the primary variable; and iv) the maps produced can corroborate the management of natural resources and land use planning in Tocantins State.
\end{abstract}

Palavras-chave adicionais: evaporation; insolation; mapping; relative humidity; temperature.

\section{Resumo}

O reconhecimento da distribuição espacial de variáveis climáticas é essencial para o planejamento do uso e da ocupação do solo. Isto é especialmente relevante em regiões de expansão da fronteira agrícola, como é o caso do Estado do Tocantins. Uma das ferramentas amplamente empregadas na espacialização de variáveis ambientais é a geoestatística, que possibilita a identificação da dependência espacial dessas variáveis. Nesse contexto, objetivou-se avaliar o desempenho dos interpoladores geoestatísticos krigagem ordinária (OK) e co-krigagem (CK), por meio do ajuste de diferentes modelos de semivariograma, e a posterior espacialização das variáveis temperatura média do ar, insolação, umidade relativa do ar e evapotranspiração potencial mensais para o Estado do Tocantins. Os principais resultados e conclusões foram: i) a análise variográfica é essencial para melhorar os resultados do mapeamento de cada variável; ii) a validação cruzada mostrou erros aceitáveis, indicando confiabilidade dos resultados; iii) o desempenho da OK sobressaiu-se ao da CK, o que pode ser explicado pela boa estrutura de dependência espacial apresentada pela variável primária, e iv) os mapas produzidos podem corroborar a gestão de recursos naturais e o planejamento do uso do solo no Estado do Tocantins.

Additional keywords: evaporação; insolação; mapeamento; temperatura; umidade relativa.

\section{Introduction}

Brazil has a large territorial extension, with the occurrence of different climatic regions. Specifically in the rainfall regime of the northern region, cold fronts occur in a more expressive way in its southern portion, while convective events and the South Atlantic and Intertropical convergence zones (SACZ and ITCZ, respectively) are more influential in other portions, defining substantial differences in rainfall. Regarding relative humidity, the southeast end of this region, influenced by the Cerrado biome and with intense action of the atmospheric blocking of the South Atlantic Anticyclone (SAAC), shows up to six dry months, whereas in most of the region, where the Amazon biome prevails, the same severity is not observed (Mello \& Silva, 2013).

Tocantins State is located in the geographic center of Brazil and in the extreme southeast of the northern region, with a predominance of the Cerrado biome in $91 \%$ of its territory (IBGE, 2010). Nearby are the Amazon (northwest) and Caatinga (northeast) biomes, resulting in considerable climatic diversity (Sousa, 2016). Due to its climatic diversity, studies to quantify 
and analyze the behavior of climatic variables such as insolation, evaporation, relative humidity, and air temperature, among others, are of great importance. This kind of research allows the description and understanding of the characteristic climatic variability (Penereiro, 2016). To better understand these variables, their mapping becomes essential as they are sampled strictly in surface meteorological stations. These mappings subsidize environmental research, highlighting water resource management, management of land use and occupation, agricultural planning, among others.

Geographic Information Systems (GIS) are consolidated tools for mapping environmental variables, allowing the construction of spatially localized databases, which, in turn, are the basis for this type of research. Allied to the GIS are the techniques of spatial interpolation, with emphasis on geostatistics, which has provided quality results in the spatialization of climatic variables (Apaydin et al., 2004; Dobesch et al., 2007; Li \& Heap, 2008; Sluiter, 2009). This technique shows great efficiency in the estimation of variables, resulting in the spatialization or generation of unbiased maps (Ávila et al., 2010). Moreover, it enables the quantification of the spatial dependence structure of the variable, allowing for inferences about the variables' spatial and temporal patterns of occurrence (Yue, 2003). Several authors have reported better performance of geostatistical techniques when compared to other spatial estimation methods (Ali et al., 2000; Goovaerts, 2000).

Among the geostatistical interpolation techniques, cokriging (CK) has been highlighted as it incorporates an auxiliary variable, densely sampled, aiming to improve the estimation efficiency (Odeh \& Mcbratney, 2000; Hengl et al., 2004; Ashiq et al., 2010; Viola et al., 2010; Cunha et al., 2012; Frazier et al., 2016). Among the auxiliary variables used in the interpolation process of climatic variables, altitude, which are densely sampled in digital elevation models, such as ASTER (Advanced Spaceborne Thermal Emission and Reflection Radiometer) and SRTM (Shuttle Radar Topography Mission), stands out.

This study mapped climatic variables (insolation, air relative humidity, potential evaporation, and mean air temperature) on a monthly scale for Tocantins State. In addition, we evaluated the performance of geostatistical interpolators kriging and cokriging by adjusting different semivariogram models, using as secondary variable the altitude extracted from a digital elevation model.

\section{Materials and methods}

\section{Study area and database}

The study area corresponds to Tocantins State, in northern Brazil, with an area of $277,720.52 \mathrm{~km}^{2}$ (IBGE, 2010). According to the Thornthwaite classification, the predominant climate is distributed between: humid climate with moderate water deficiency in the winter (B1wA'a'), mostly in northern and south- western portions; subhumid-humid climate with moderate water deficiency in the winter (C2wA'a'), extending from the central part of the state to the southern region; and humid-subhumid climate with small water deficiency (C2w2A'a'), characteristic of the southeast region of the state (SEPLAN, 2012). The average annual rainfall varies from $1,200 \mathrm{~mm}$ to $2,100 \mathrm{~mm}$ (SEPLAN, 2012).

The relief is flat, with a predominance of residual plateaus. Tocantins has little altimetric variation when compared to other Brazilian states, with altitudes between 55 and 1223 meters. The lowest altitudes are found in the western portion, while the highest ones are located in the eastern portion, where Serra Traíras (or Serra das Palmas) is situated, near the border with Goiás State (IBGE, 2010). Figure 1B shows such altimetric variations by means of the digital elevation model provided by Shuttle Radar Topography Mission (SRTM) (Farr et al., 2007).

The database consists of monthly mean climatic variables computed from historical series from 26 conventional meteorological stations, made available by the National Institute of Meteorology (INMET, 1992) and distributed throughout the state and its vicinity, as shown in Figure 1A. Climatic variables studied were insolation (hours), potential evapotranspiration (mm), air relative humidity $(\%)$, and mean air temperature $\left({ }^{\circ} \mathrm{C}\right)$.

\section{Exploratory analysis and mapping of climatic variables}

Exploratory analysis was carried out as recommended by Ávila et al. (2010) to verify whether the historical series meet the fundamental premises established by geostatistics, especially the intrinsic hypothesis (Journel \& Huijbrets, 1978; Isaaks \& Srivastava, 1978).

Subsequently, the evaluation and modeling of the spatial dependence structure of the climatic variables were carried out. The following theoretical semivariogram models were adjusted according to the Weighted Least Squares (WLS) method: exponential (EXP), spherical (SPH), and Gaussian (GAU). The quality of the adjustment was evaluated by the spatial dependence degree (DD). The DD is determined by the ratio between the structural variance $(\mathrm{C} 1)$ and the threshold $(\mathrm{C} 0+\mathrm{C} 1)$, having the following classification (Cambardella et al., 1994): <25\% (weak), between 25 and $75 \%$ (moderate), $>75 \%$ (strong).

For each situation analyzed, the semivariogram model with the largest DD was selected to map the climatic variables through geostatistical interpolators ordinary kriging (OK) and cokriging (CK). Such selection seeks to identify the best spatial dependence structure modeled, which results in a more accurate representation of the phenomenon, i.e., better quality in the estimation. Geostatistical interpolator CK was applied to evaluate the improvements in estimation efficiency, using an auxiliary (secondary) variable during the interpolation process. The auxiliary variable used was the altitude extracted from the SRTM digital elevation model, with a spatial resolution of 90 meters for the entire Tocantins State (Farr et al., 2007). The applica- 
bility of altitude as a secondary variable was analyzed using the Pearson correlation coefficient ( $r$ ). This coefficient allows to check the correlation direction (by its signal, positive or negative) and the magnitude, which can be classified, according to Franzblau (1958), as: $|\mathrm{r}|<0.2$ very weak; $0.2<|\mathrm{r}|<0.4$ weak; $0.4<|\mathrm{r}|<0.6$ moderate; $0.6<|r|<0.8$ strong; and $|r|>0.8$ very strong.

After adjusting and selecting the most suitable semivariogram, maps of monthly climatic variables (potential insolation, potential evaporation, relative humidity, and mean temperature) were generated through geostatistical interpolators OK and CK. The performance analysis of interpolators was done through cross-validation, with the mean error (ME) being quantified as follows:

$M E(\%)=\frac{1}{n} \times \sum_{i=1}^{n} \frac{\left|\hat{Z}_{x i}-Z_{x i}\right|}{\hat{Z}_{x i}}$

wherein $n$ is the number of data, $\hat{Z}_{x i}$ is the value observed at point $\mathrm{i}$, and $Z_{x i}$ is the value predicted by the interpolator at point i.

All stages of application of the geostatistical techniques were developed from ArcGIS 9.2® software (ESRI, 2004).
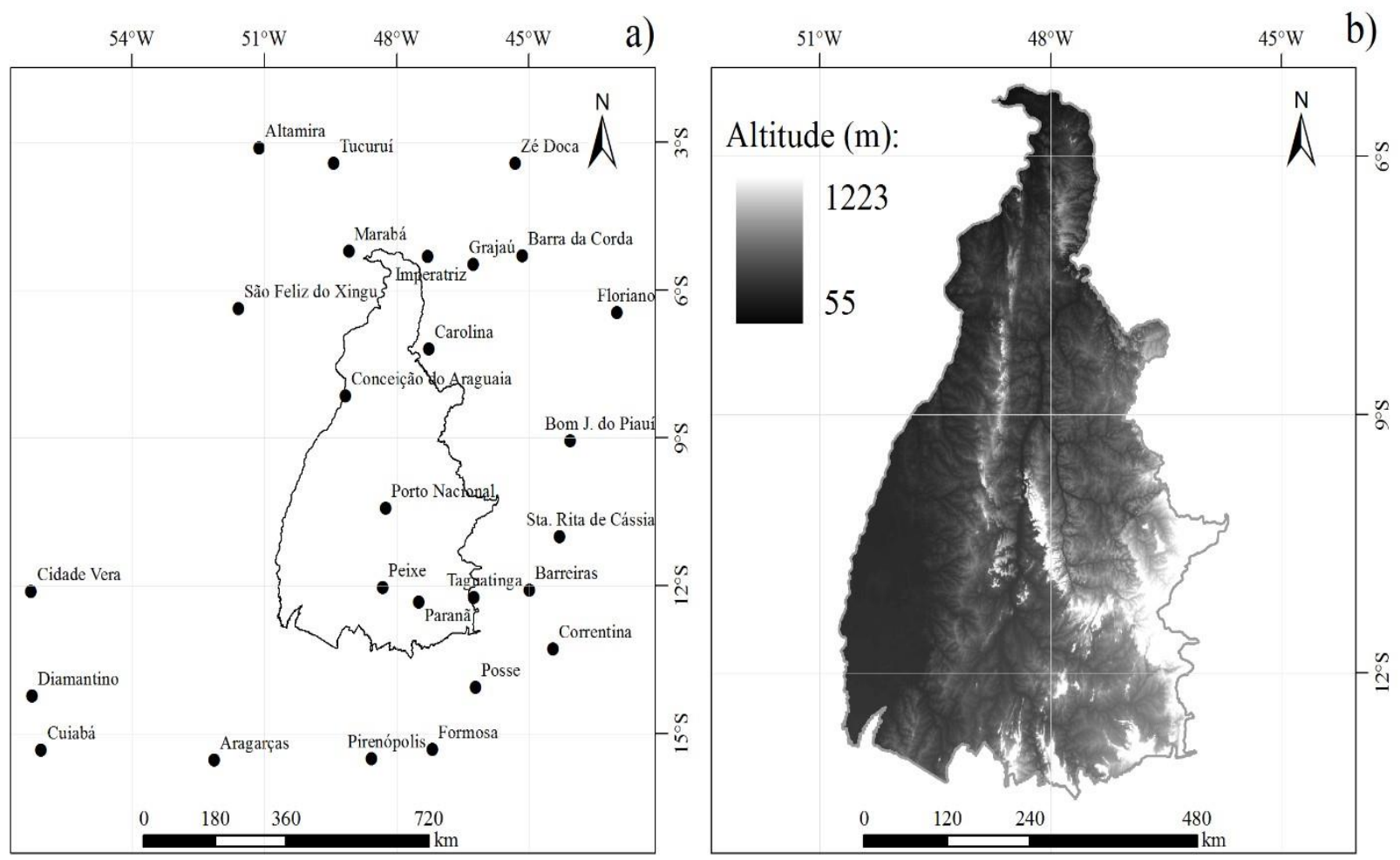

Figure 1 - Location of the conventional meteorological stations of the National Institute of Meteorology (INMET) used (A), and SRTM digital elevation model for the state of Tocantins (B).

\section{Results and discussion}

\section{Analysis of geostatistical interpolators}

Table 1 shows the parameters of the semivariogram models $\left(\mathrm{C}_{0}=\right.$ nugget effect; $\mathrm{C}_{0}+\mathrm{C}_{1}=$ threshold; and $A=$ range), the spatial dependence degree (DD), and the mean error (ME) for the interpolator selected to map each variable, chosen based on the criterion of higher spatial dependence degree.

Regarding the performance of the semivariogram models, Table 1 shows no predominance of a specific model. From a total of 48 analyzed variables, the exponential, spherical, and Gaussian models stood out in 15, 16, and 17 analyses, respectively. For mean air temperature the exponential model stood out in 8 situations; for relative humidity, the spherical model was highlighted in 5 situations; while the Gaussian model adjusted better for insolation and evaporation in
7 and 6 situations, respectively. These results show the importance of variographic analysis prior to mapping, seeking to select the theoretical semivariogram model that best represents each variable under study.

Regarding DD and range $(A)$, in general, the existence of a spatial dependence structure was observed for all climatic variables. This fact indicated that the process of interpolation through the adjusted models showed a relevant degree of reliability. Insolation presented lower DD values (from 33 to $89 \%$ ), with a "moderate" spatial dependence class (25 to 75\%). However, for the other variables DD was predominantly "strong" (>75\%) in most analyses. Values of the order of hundreds or thousands of kilometers were observed in all situations, demonstrating the wide scope of spatial dependence and the potential of using geostatistical techniques. 
Table 1 - Interpolator and parameters of semivariogram models with higher degree of spatial dependence (DD) for each analysis followed by mean error (ME).

\begin{tabular}{|c|c|c|c|c|c|c|c|c|c|c|c|c|}
\hline & Jan & Feb & Mar & Apr & May & Jun & Jul & Aug & Sep & Oct & Nov & Dec \\
\hline \multicolumn{13}{|c|}{ Insolation } \\
\hline Interp & OK & OK & OK & OK & OK & OK & OK & $\mathrm{OK}$ & $\mathrm{CK}$ & CK & & OK \\
\hline & GAU & GAU & ESF & EXP & ESF & GAU & $E S$ & ESF & $\mathrm{GA}$ & & & GAU \\
\hline & & 414 & 382 & 208 & 836 & 785 & 72 & 687 & 10 & 609 & 27 & 675 \\
\hline & 42 & 933 & 1048 & 1727 & 742 & 587 & 74 & 1285 & 10 & 7. & 3 & 337 \\
\hline & 1456 & 56 & 456 & 1456 & 1113 & 396 & 568 & 723 & 1103 & 1194 & 1609 & 1435 \\
\hline & 42 & 69 & 73 & 89 & 47 & 43 & & 65 & 49 & 55 & 54 & 33 \\
\hline & 14 & 14 & 13 & 12 & 11 & 13 & 1 & 1 & 17 & 1 & 16 & 15 \\
\hline \multicolumn{13}{|c|}{ Evaporation } \\
\hline erp & CK & CK & OK & OK & CK & CK & $\mathrm{CK}$ & OK & CK & CK & CK & DK \\
\hline$N$ & SPH & EXP & GAU & EXP & SPH & GAU & GAU & GAU & GAU & SPH & SPH & GAU \\
\hline & 11 & 3 & 145 & 0 & 449 & 1061 & 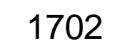 & 2156 & 822 & 0 & 3 & 72 \\
\hline & 447 & 669 & 502 & 923 & 1230 & & 50 & 5404 & 5952 & 582 & 140 & 552 \\
\hline & 1172 & 1629 & 456 & 1456 & 291 & 1456 & 243 & 368 & 1031 & 1198 & 823 & 489 \\
\hline & 98 & 100 & 78 & 100 & 73 & 62 & 63 & 71 & 88 & 100 & 100 & 88 \\
\hline & 15 & 14 & 12 & 17 & 22 & 20 & 1 & $1 s$ & 14 & & 12 & 14 \\
\hline \multicolumn{13}{|c|}{ Relative Humidity } \\
\hline erp. & $\mathrm{K}$ & OK & OK & OK & CK & CK & CK & CK & CK & OK & CK & OK \\
\hline N & & & EXP & EXP & SPH & SPH & GAU & $\mathrm{PH}$ & $\mathrm{SPH}$ & GAU & $A U$ & DH \\
\hline & 4 & 0 & 0 & 0 & 0 & 16 & 48 & 30 & 5 & 2 & 6 & 0 \\
\hline & 32 & 37 & 33 & 47 & 65 & 85 & 95 & 179 & 190 & 87 & 36 & 29 \\
\hline & 233 & 456 & 1456 & 1456 & 1153 & 1135 & 1055 & 1168 & 1087 & 781 & 735 & 811 \\
\hline & 89 & 00 & 100 & 100 & 100 & 84 & 66 & 86 & 98 & 98 & 85 & 100 \\
\hline & & 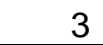 & 0 & 3 & 4 & 7 & 9 & 1 & & & 2 & 1 \\
\hline \multicolumn{13}{|c|}{ Mean air temperature } \\
\hline & OK & OK & OK & OK & CK & OK & OK & OK & OK & OK & CK & CK \\
\hline & & & $X P$ & $X P$ & $\mathrm{SPH}$ & EXP & EXP & EXP & $A U$ & EXP & $\mathrm{PH}$ & $\mathrm{PH}$ \\
\hline & 0 & 0 & 0 & 0 & 0 & 0 & & 0 & 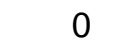 & & & 0 \\
\hline & 1 & 1 & 1 & 2 & 3 & 6 & 6 & 5 & 2 & 3 & 3 & 2 \\
\hline & 1456 & 456 & 1456 & 1456 & 1194 & 1456 & 1456 & 1456 & 623 & 1456 & 1213 & 1235 \\
\hline & 88 & 97 & 96 & 100 & 100 & 100 & 100 & 100 & 83 & 100 & 100 & 100 \\
\hline & 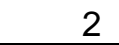 & 2 & 2 & 2 & 2 & 4 & 4 & 4 & 3 & 3 & 2 & L \\
\hline
\end{tabular}

Interp. = Interpolator; Mod. = Model; GAU = Gaussian; SPH = spherical; EXP = exponential; $\mathrm{C}_{0}=$ nugget effect; $\mathrm{C}_{0}+\mathrm{C}_{1}=$ threshold; $\mathrm{A}=$ range; $\mathrm{OK}=$ ordinary kriging; $\mathrm{CK}=$ cokriging.

Regarding the general performance of geostatistical interpolators $\mathrm{OK}$ and $\mathrm{CK}$, among the 48 analyses performed, interpolator OK showed better results in 28 situations, while CK excelled in 20 . However, when evaluating the interpolators individually for each variable it was observed that for insolation and mean air temperature OK stood out in $75 \%$ of the analyses. On the other hand, for evaporation, CK stood out in $60 \%$ of the analyses. For relative humidity, both interpolators outperformed in 6 analyses each. Although an improvement in the quality of the geostatistical interpolation was expected when CK was used, since an additional and thickly sampled information was included in the process, this was not observed in all studied situation. Such behavior may be associated with the correlation between the primary and the auxiliary variable, as according to Goovaerts $(1999,2000)$, a strong correlation is fundamental to obtain an improvement in the estimation by CK.

Table 2 shows the correlation between the studied variables and the altitude extracted from the SRTM digital elevation model.

When analyzing Table 2, it can also be inferred that the lowest absolute values of correlation were for the variable insolation (ranging from very weak to moderate), for which CK stood out in only $25 \%$ of the analyses. For evaporation, which had a moderate or strong positive correlation between January and October, interpolator CK performed better, standing out in $60 \%$ of the analyses. On the other hand, for relative humidity and air temperature, which showed negative correlation ranging from weak to very strong, interpolator CK performed worse compared to OK. A justification for the lower performance of CK in situations in which there is a strong or very strong correlation between the primary and auxiliary variables is related to the database and to the validation process used in the present study. The database is limited to the location of the INMET conventional meteorological stations, not including remote sites, in regions with adverse relief, such as peak points in mountain ranges. These are situations for which CK estimation quality is expected to increase when compared to OK. Regarding the cross-validation process used in the present study, the justification for its adoption is the reduced availability of meteorological stations with a historical 
series available for Tocantins State and nearby. This made it impossible to separate an exclusive database for validation, which would be a more rigorous validation process.

Table 2 - Pearson correlation coefficient ( $r$ ) between the variables (insolation - IN, potential evapotranspiration $\mathrm{EV}$, air relative humidity - $\mathrm{RH}$, and mean air temperature - $\mathrm{MT}$ ) and the auxiliary variable (altitude) used in the geostatistical interpolation by cokriging.

\begin{tabular}{lcrrrrrrrrrrr}
\hline Variable & Jan & Feb & Mar & Apr & May & Jun & \multicolumn{1}{c}{ Jul } & Aug & Sep & Oct & Nov & Dec \\
\hline IN & 0,40 & 0,57 & 0,57 & 0,51 & 0,31 & 0,13 & 0,10 & 0,37 & 0,39 & 0,38 & 0,39 & 0,24 \\
EV & 0,58 & 0,77 & 0,76 & 0,72 & 0,66 & 0,54 & 0,50 & 0,57 & 0,65 & 0,48 & 0,17 & 0,08 \\
RH & $-0,57$ & $-0,70$ & $-0,72$ & $-0,80$ & $-0,75$ & $-0,69$ & $-0,62$ & $-0,62$ & $-0,62$ & $-0,51$ & $-0,33$ & $-0,33$ \\
MT & $-0,68$ & $-0,66$ & $-0,73$ & $-0,71$ & $-0,75$ & $-0,73$ & $-0,69$ & $-0,63$ & $-0,49$ & $-0,63$ & $-0,71$ & $-0,81$ \\
\hline
\end{tabular}

\section{Mapping of climatic variables}

The maps generated by the interpolators that presented the best adjustment quality (Table 1) for insolation, evaporation, relative humidity, and mean air temperature in Tocantins State are shown in Figures 2 to 5 , respectively.

Based on the insolation maps (Figure 2), a similar pattern was observed throughout the analyzed months, with lower values in the northwest portion of the State, and a gradual increase southeastward. The period from April to August accounted for a concentration of the highest values near the south, specifically in the center-south.
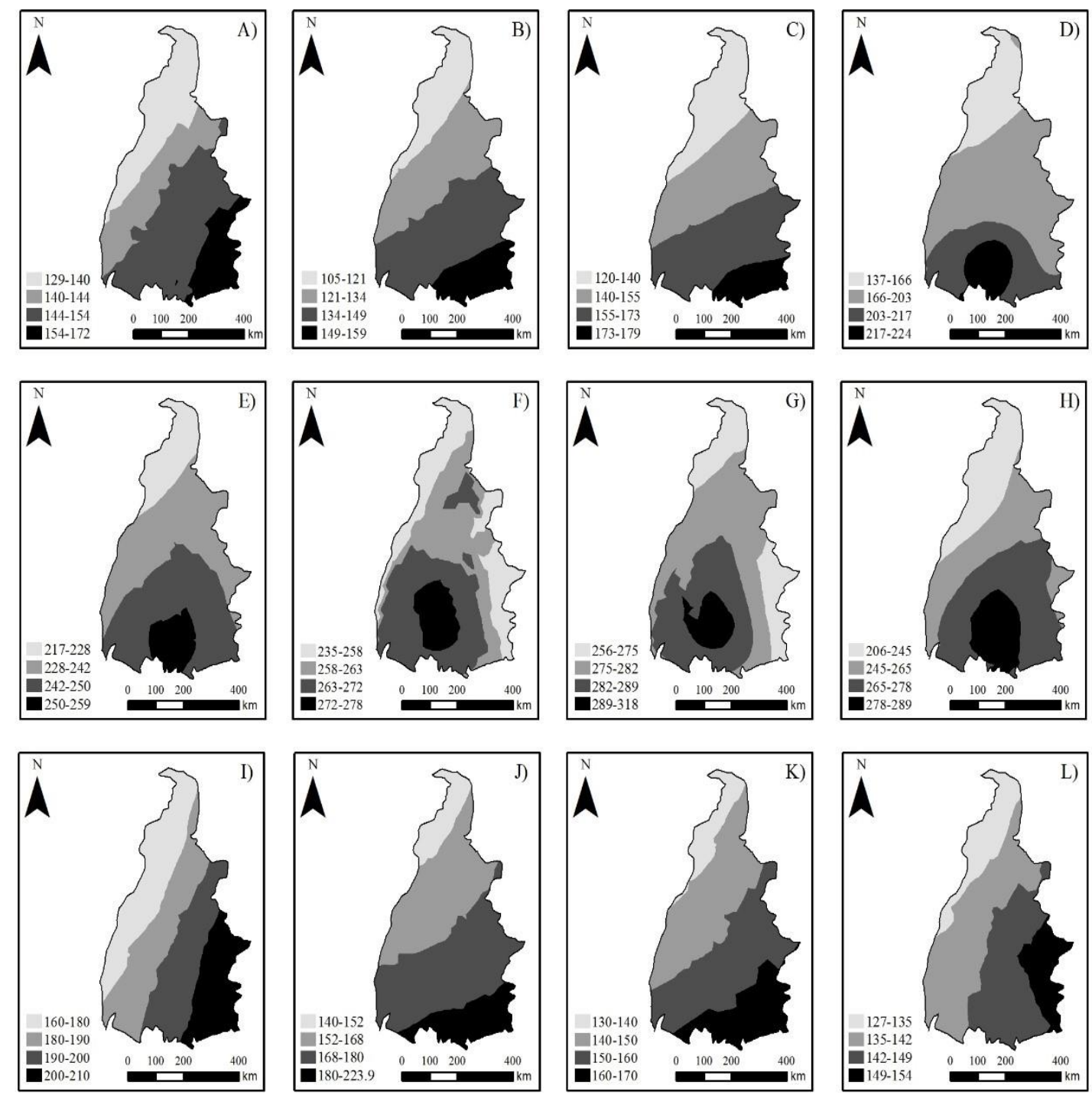

Figure 2 - Insolation maps (hours) for January (A), February (B), march (C), April (D), may (E), June (F), July (G), August $(\mathrm{H})$, September (I), October $(\mathrm{J})$, November $(\mathrm{K})$ and December $(\mathrm{L})$, in the state of Tocantins. 
For relative humidity (Figure 3 ), there was a decreasing gradient from the northwest direction to the southeast of Tocantins State, thus with the lowest relative humidity in the east and southeast. This gradient is exactly the opposite of that observed for insolation and again is associated with environmental characteristics of the biomes occurring there. In the southeast of the state, the atmospheric blocking of the South Atlantic Anticyclone (SAAC) acts with greater intensity, reduc- ing the transport of atmospheric humidity in some periods of the year (Reboita et al., 2010). It should also be considered that the eastern part of the state is bordered by arid areas, including the occurrence of Caatinga biome in some places. Therefore, lower rainfall and relative humidity are expected in this range. In this situation, the cloud cover is reduced throughout the year compared to the northwest of the state, justifying the higher insolation values.
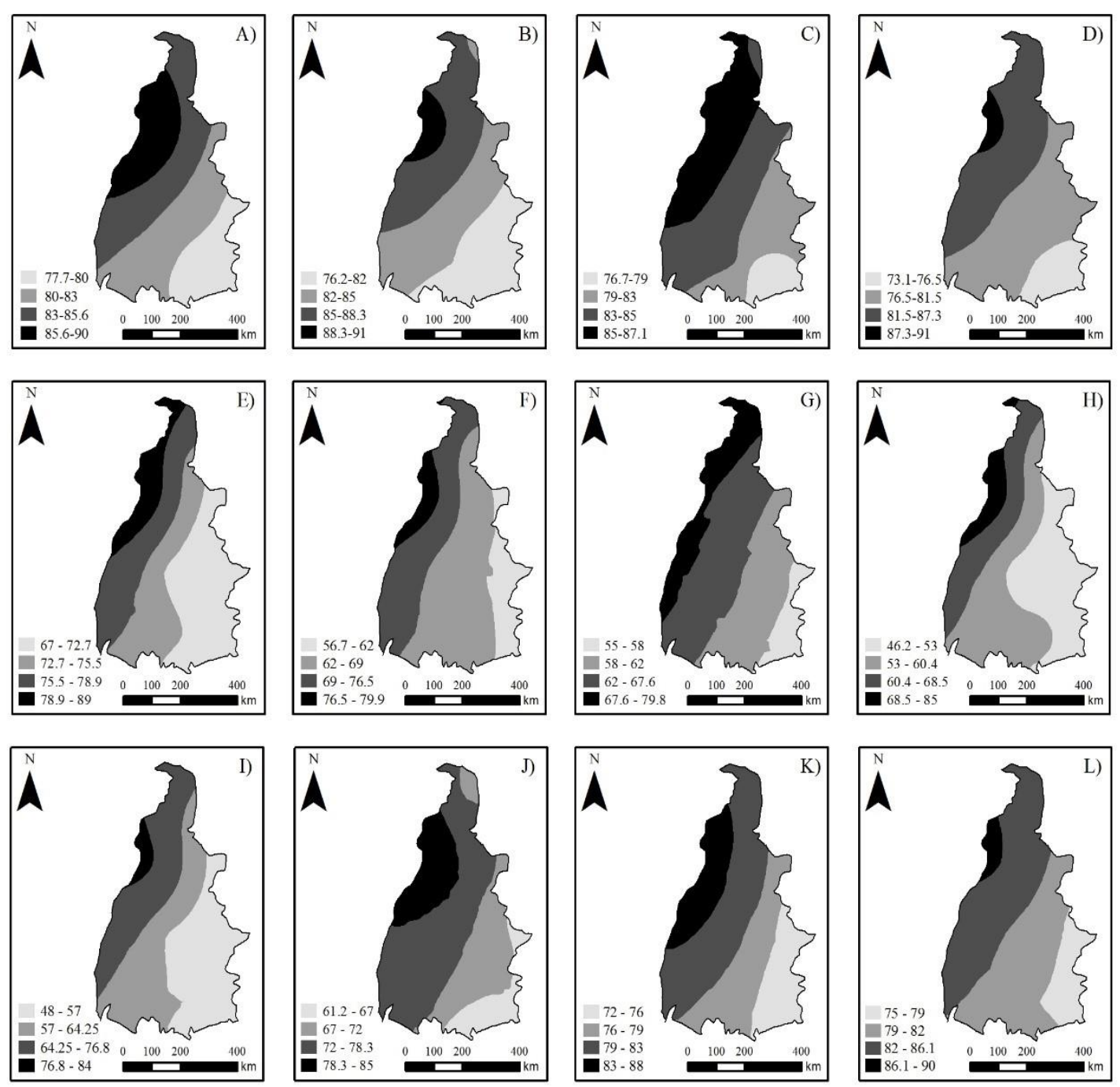

Figure 3 - Air relative humidity (\%) maps for January (A), February (B), March (C), April (D), May (E), June (F), July (G), August (H), September (I), October (J), November (K) and December (L), in the state of Tocantins.

Figure 4 shows the monthly temperature maps for Tocantins. The state has a small thermal amplitude, with high mean temperatures in all months of the year, which confers the characteristic of megathermal climate according to the classification of Thornthwaite and Mather (Sousa, 2016). The hottest month is September, with temperatures over $25^{\circ} \mathrm{C}$ throughout the state. The lowest temperatures occur in July, although being greater than $21.2 \stackrel{\circ}{\circ}$ throughout the territory. The northern region, with the lowest latitude, stood out as having the highest mean temperature during most of the year, except for the months of February, May, September, and October, for which the center and/or center-east regions also show higher temperatures. Throughout the year, the lowest mean temperatures are observed in the southeast of Tocantins, a region with greater latitude when compared to the north, and that also presented higher altitudes (Figure 1). 

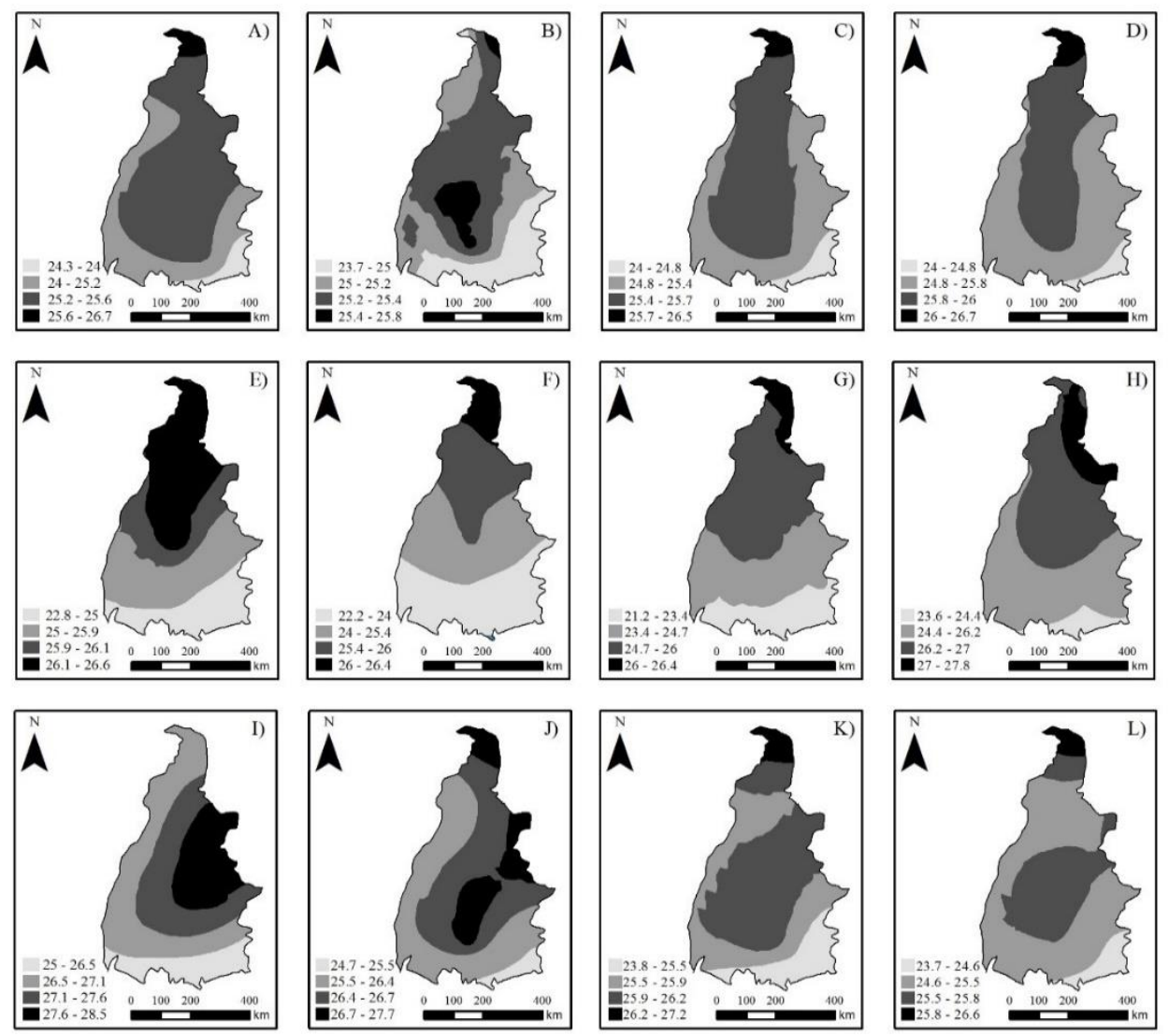

Figure 4 - Mean air temperature $\left({ }^{\circ} \mathrm{C}\right)$ maps for January $(A)$, February $(B)$, March $(C)$, April $(D)$, May $(E)$, June $(F)$, July $(G)$, August $(H)$, September $(I)$, October $(J)$, November $(K)$ and December $(L)$, in the state of Tocantins.
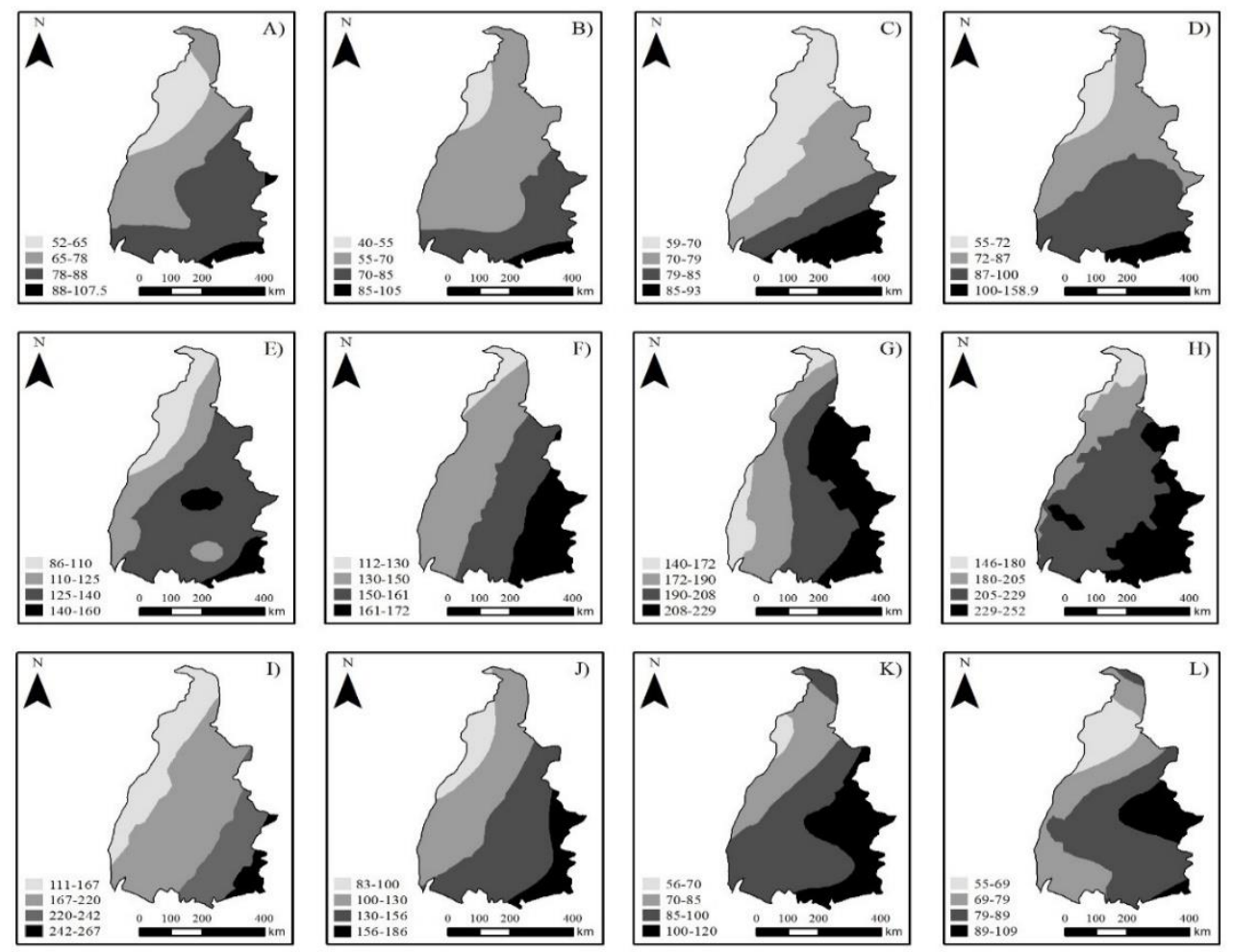

Figure 5 - Potential evapotranspiration $(\mathrm{mm})$ maps for January $(A)$, February $(B)$, March $(C)$, April (D), May $(E)$, June $(F)$, July $(G)$, August $(H)$, September $(I)$, October $(J)$, November $(K)$ and December $(L)$, in the state of Tocantins. 
Figure 5 shows the monthly potential evaporation maps for Tocantins State. This variable showed a similar pattern to insolation, that is, lower values in the northwest portion, with gradual increase in the southeast direction of the state. This finding is explained, among other things, by the occurrence of the variables relative humidity and insolation. Taking as reference the northern region, in which the potential evaporation recorded by the Piche evaporimeter is lower, greater relative humidity and lower insolation are verified, which may explain the lower atmospheric evaporation potential when compared to the southeast of the state.

\section{Conclusions}

Spherical, exponential, and Gaussian semivariogram models differed in the adjustment for the climatic variables studied in Tocantins State, evidencing the importance of a variographic analysis prior to mapping.

There was a spatial dependence structure for all climatic variables, indicating that the interpolation process through geostatistical techniques can provide good results. Regarding the general performance of geostatistical interpolators ordinary kriging $(\mathrm{OK})$ and cokriging (CK), OK was shown to be superior in most situations.

The maps of monthly insolation, mean air temperature, relative humidity, and potential evaporation for Tocantins State are important tools for understanding the dynamics of these variables in the different biomes and ecological regions existing there. Results can subsidize the management and planning of natural resources.

\section{Acknowledgements}

The authors thank the National Council for Scientific and Technological Development (CNPq) for supporting the research project (Process CNPq No. 482075/2013-9, 305854/2015-1 e 308947/2018-5).

\section{Referências}

Ali A, Abtew W, Horn SV, Khanal N (2000) Temporal and spatial characterization of rainfall over central and south Florida. Journal of the American Water Resources Association 36(4): 833-848.

Apaydin H, Sonmez FK, Yildirim YE (2004) Spatial Interpolation Techniques for Climate Data in the GAP Region in Turkey. Climate Research 28: 31-40.

Ashiq MW, Zhao CY, Ni J, Akhtar M (2010) GIS-based high-resolution spatial interpolation of precipitation in mountain- plain areas of Upper Pakistan for regional climate change impact studies. Theoretical and Applied Climatology 99: 239-253.
Avila LF, Mello CR, Silva AM (2010) Continuidade e distribuição espacial da umidade do solo em bacia hidrográfica da Serra da Mantiqueira. Revista Brasileira de Engenharia Agrícola e Ambiental 14(12): 1257-1266.

Cambardella CA, Moorman TB, Parkin TB, Karlen DL, Novak JM, Turco RF, Konapka AE (1994) Field scale variability of soil properties in Central lowa soils. Soil Science Society of America Journal 58(5): 1501-1511.

Cunha AM, Lani JL, Santos GR, Filho EIF, Trindade FS, Souza E (2013) Espacialização da precipitação pluvial por meio de krigagem e co-krigagem. Pesquisa Agropecuária Brasileira 48(9): 1179-1191.

Dobesch H, Dumolard P, Dyras I (2007) Spatial Interpolation for Climate Data: The Use of GIS in Climatology and Meteorology. Wiley-ISTE. 284p.

ESRI - Environmental Systems Research Institute (2004) ArcGIS 9: Getting started with ArcGIS. Redlands. 265p.

Farr TG et al. (2007) The Shuttle Radar Topography Mission. Reviews of Geophysics 45(2): 1-33.

Franzblau A (1958) A primer of statistics for non-statisticians. New York: Harcourt, Brace \& World. 150p.

Frazier A, Giambelluca T, Diaz HF, Needham H (2016) Comparison of geostatistical approaches to spatially interpolate month-year rainfall for the Hawaiian Islands. International Journal of Climatology 36(3) 1459-1470.

Goovaerts P (1999) Using elevation to aid the geostatistical mapping of rainfall erosivity. Catena 34 : 227242.

Goovaerts P (2000) Geostatistical approaches for incorporating elevation into the spatial interpolation of rainfall. Journal of Hydrology 228: 113-129.

Hengl T, Heuvelin GBM, Stein A (2004) A generic framework for spatial prediction of soil variables based on regression-kriging. Geoderma 120: 75-93.

IBGE. Censo Demográfico 2010 (2010). Disponivel em:http://www.ibge.gov.br/estadosat/perfil.php?sigla=to. Acesso em: outubro de 2017

INMET - INSTITUTO NACIONAL DE METEOROLOGIA. Normais Climatológicas 1961 a 1990. Brasília, 1992.Disponivel em: http://www.inmet.gov.br/portal/index.php?r=clima/nor maisClimatologicas. Acesso em: janeiro de 2018

Isaaks EH, Srivastava M (1978) An introduction to applied geostatistics. New York: Oxford University, 1978. 
Journel AG, Huijbregts CJ (1978) Mining geostatistics. London: Academic.

Li J, Heap AD (2008) A Review of Spatial Interpolation Methods for Environmental Scientists. Geoscience Australia. 137p.

Mello CR, Silva AM (2013) Hidrologia: Princípios e aplicações em sistemas agrícolas. Lavras: UFLA. 455p.

Odeh IOA, Mcbratney AB (2000) Using AVHRR images for spatial prediction of clay content in the lower Namoi Valley of eastern Australia. Geoderma 97: 237254.

Penereiro JC, Martins LLS, Beretta VZ (2016) Identificação de variabilidades e tendências interanuais em medidas hidro- climáticas na região hidrográfica do Tocantins- Araguaia, Brasil. Revista Brasileira de Climatologia 18: 219-841.

Reboita MS, Gan MA, Rocha RP, Ambrizzi T (2010) Regimes de precipitação na América do Sul: uma revisão bibliográfica. Revista Brasileira de Meteorologia 25(2): 185-204.
Sousa FHM (2016) Regionalização climática de Thorntwhaite e Mather para o estado do Tocantins. Gurupi - TO, UFT.

SEPLAN - Secretaria do Planejamento e da Modernização da Gestão Pública (2012). Atlas do Tocantins: subsídios ao planejamento da gestão territorial. Palmas: Seplan, 80p.

Sluiter R (2009) Interpolation Methods for Climate Data: Literature Review. KNMI, R\&D Information and Observation Technology De Bilt, International report.

Viola RV, Mello CR, Pinto DBF, Mello JM, Ávila LF (2010) Métodos de interpolação espacial para o mapeamento da precipitação pluvial. Revista Brasileira de Engenharia Agrícola e Ambiental 14(9): 970-978.

Yue W, Xu J, Hongjuan L, Xu L (2003) Applications of Spatial Interpolation for Climate Variables Based on Geostatistics: A case study in Gansu Province, China. Geographic Information Sciences 9. 